\title{
Microbially Induced Calcium Carbonate Precipitation: A Sustainable Approach to Reinforce Cement Concrete
}

\author{
Manisha Parmar ${ }^{1 *}$ and Priyanka Kamboj ${ }^{2}$ \\ ${ }^{1}$ Department of Microbiology, College of Basic Sciences and Humanities, Punjab \\ Agricultural University, Ludhiana, India \\ ${ }^{2}$ Department of Agriculture, Dev Samaj College for Women, Ferozepur City, Punjab, \\ India \\ *Corresponding Author: Manisha Parmar, Department of Microbiology, College of \\ Basic Sciences and Humanities, Punjab Agricultural University, Ludhiana, India.
}

Received: July 24, 2021;

Published: August 18, 2021

(C) All rights are reserved by Manisha Parmar and Priyanka Kamboj.

\section{Abstract}

Cement is among the essential components of concrete, which is a widely known construction material. Despite the reliability and durability of concrete, extant of cracks results in defected concrete and subsequently accelerate concrete deterioration. Taking into consideration the relatively expensive reconstruction and maintenance of structural concrete, Microbially Induced Calcium Carbonate Precipitation (MICCP) or Bio-cementation has been recommended as one of the solutions to develop eco-friendly structural materials. It is a naturally occurring phenomenon which appertains to the precipitation and deposition of calcium carbonate as a consequence of peculiar action of ureolytic bacteria. Bio-cementation by urea hydrolysis is amongst the most productive ways to implement the method and is induced by a chain of reactions driven by urease. Apart from repairing cracks and concrete, bio-cementation has numerous applications, for instance consolidation of sand and filling of pores between the soil particles. This review focuses on general mechanism of urease enzyme and microbially induced calcium carbonate precipitation.

Keywords: Biocementation; Microbially Induced Calcium Carbonate Precipitation; Calcium Carbonate; Ureolysis; Urease Enzyme

\section{Introduction}

In this epoch, majority of the populace is looking forward to urbanization and as a result of this the construction industries are gaining much importance [1]. The construction materials such as bricks and concrete are subjected to the weathering action of several physical, chemical and biological factors [2]. The inexorable dissolution of the mineral matrix as a consequence of weathering leads to an increase in porosity, and as a result, a decrease in mechanical strength of the construction material [3] also cracks in the concrete intensify the deterioration of embedded steel bars as ingression rate of corrosive chemicals including chloride ions in to the concrete structure increases [4].

The conventional conservation method of preserving and protecting these materials involves application of organic polymers, alkoxysilanes, or inorganic materials to fill the cracks and employ- ing water repellents and stone consolidates [5]. However, these methods come with many limitations, which include limited longterm performance, physical-chemical incompatibility, alteration in the appearance of the construction material and formation of superficial films [6].

Microbially induced calcium carbonate precipitation

In recent years, Microbially Induced Calcium Carbonate Precipitation (MICCP) or Bio-cementation has emerged as an environment friendly method to protect damaged buildings and ornamental stones [7]. It comes under a broader category of science called Bio-mineralization where an organism creates a local microenvironment with conditions that permits the optimal extracellular chemical precipitation of mineral phases [8]. This conservation strategy relies on bacterially instigated precipitation of calcium carbonate on limestone which builds a protective layer on the sur- 
face of cement concrete [9]. Over the time, this layer when supplied with nutrient medium eventually results in the precipitation of calcite and forma a coating which is highly coherent.

Like other mineralization processes, precipitation of calcium carbonate $\left(\mathrm{CaCO}_{3}\right)$ occurs by three different mechanisms: biologically controlled, biologically influenced and biologically induced. In biologically controlled mineralization, the organism directs the process, i.e., nucleation and development of mineral particles, to a great degree. The organism synthesizes minerals in a form that is unique to that species, independent of environmental conditions. Examples of controlled mineralization are magnetite formation in magneto tactic bacteria [10]. In Biologically influenced mineralization, cell surface organic matter (EPS) brings about the passive mineral precipitation [11]. However, calcium carbonate production by bacteria is generally regarded as "Induced", where microbial activities result in chemical modification of the environment which leads to the precipitation of minerals [12]. During MICCP, one or more metabolic products $\left(\mathrm{CO}_{3}{ }^{2-}\right)$ secreted by organism reacts with ions $\left(\mathrm{Ca}^{2+}\right)$ present in the environment, resulting in the subsequent precipitation of minerals. Earlier, it was proposed that calcium carbonate precipitation occur via different mechanisms, out of which urea hydrolysis carried out by urease enzyme is the most extensively employed [13].

\section{Urease enzyme and its mechanism}

Urease (Urea amidohydrolase; EC 3.5.1.5) is widely distributed in soil and aquatic environments. It executes a single catalytic function i.e. hydrolysis of urea $\left(\mathrm{H}_{2} \mathrm{~N}-\mathrm{CO}-\mathrm{NH}_{2}\right)$, into ammonia and carbonic acid as final end products:

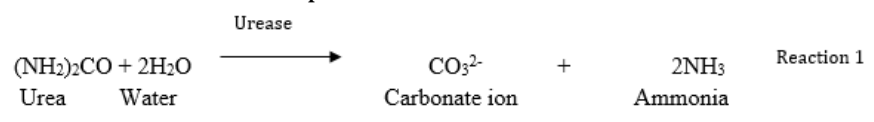

Through the hydrolysis of urea, bacteria release carbonate ions into soil or water that can bind with calcium to form calcium carbonate and its metastable polymorph, calcite:

$$
\underset{\text { Calcium }}{\mathrm{Ca}^{2+}+\underset{\text { Carbonate }}{\mathrm{CO}_{3}^{2-}} \longrightarrow \text { Calcium carbonate }} \underset{\mathrm{CaCO}_{3}}{\longrightarrow} \text { Reaction 2 }
$$

Calcium carbonate precipitation is an uncomplicated chemical process which is governed mainly by four pivotal factors: (1) calcium concentration, (2) dissolved inorganic carbon (DIC) concentration, (3) pH and (4) availability of nucleation sites [14]. In addition, several other environmental parameters in particular salinity and temperature of the suspension have an impact on the precipitation process [15]. Under appropriate conditions, most of the bacteria are capable of inducing carbonate precipitation. Additionally, carbonate particles can also be supplied by ion exchange across the cell membrane.

The metabolic pathway employed by the bacteria has a considerable impact on the rate of carbonate precipitation, and consequently, on the rate of calcium carbonate precipitation. For the biodeposition to happen, utilisation of the supplied organic acids [16] and oxidative deamination of supplied amino acids must occur. The precipitated polymorphs (calcite) also influence the bio-deposition process as they affect the amount and type of precipitates that are formed [17]. The presence of well developed rhombohedral calcite crystals results in marked consolidating effect compared to the presence of tiny acicular vaterite crystals [18].

Bacteria also control the calcium carbonate precipitation by acting as nucleation site; at neutral $\mathrm{pH}$, several positively charged metal ions bound to the negatively charged groups on the cell wall [19]. Such bound metal ions viz. calcium may further react with anions e.g. carbonate to form an insoluble salt (e.g. calcium carbonate). The metal salt in the presence of sufficient amount of required cations and anions commences mineral formation by functioning as nucleation site. The carbonate in this reaction potentially is an outcome of bacterial metabolism or it may have an abiotic origin. Specific bacterial outer structures viz., glycocalyx and parietal polymers comprising of exo-polysaccharides and amino acids play an indispensable role in the morphology and mineralogy of bacterially induced carbonate precipitation [20].

\section{Ureolytic bacteria and cementation reaction}

Bacterial calcium carbonate formation (Figure 1) through urea hydrolysis is well known as Bacterial Calcite Precipitation. It is a highly desirable process as it is pollution free and natural and it has many advantages over the ordinary cement; it needs a much shorter time; it is suitable for in-situ process; raw material of bio cement are produced at a lower temperature and can be used as eco-construction material as it consumes less energy and less $\mathrm{CO}_{2}$ [21]. 


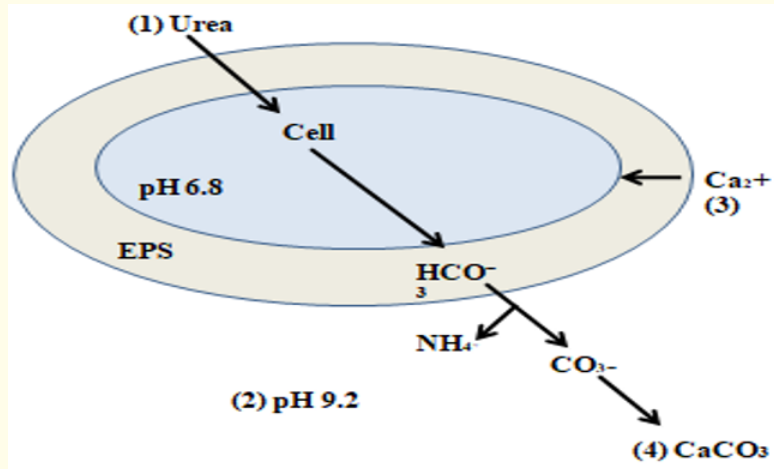

Figure 1: Steps involved in $\mathrm{CaCO}_{3}$ precipitation: (1) Urea hydrolysis (2) $\mathrm{pH}$ increase of micro-environment (3) Surface adsorption of $\mathrm{Ca} 2+$ ions and (4) nucleation and crystal growth. Eps stands for exo-polysaccharide in the case of the presence of exo-polysaccharide surrounding the ureolytic cells.

There are many applications of MICCP; the most important one is strength development. Bacterial cultures improve the strength of cement sand mortar and are reported to repair the cracks on surfaces of concrete structures [22]. The "Bacterial concrete" is prepared by adding spore forming bacteria in the concrete that are capable of continuously precipitating calcite. Bouquet., et al. (1973) were among the first to demonstrate the ability of soil bacteria to precipitate calcium carbonate under laboratory conditions.

The microbiological remediation of cracks in concrete was analyzed and it was reported that specimens with cracks filled with bacteria, nutrients and sand indicated a significant increase in the compressive strength and stiffness values when compared with those without cells [24]. In a study carried out to investigate the compressive strength of the remediated cubes, it was found that the compressive strength increase considerably after they were applied with the bioconcrete formed with B. sphaericus [25]. The selection of the bacteria depends on the ability of bacteria to survive under alkaline environment. Most of the microorganisms die in an environment with $\mathrm{pH}$ value of 10 or above [26].

\section{Conclusion}

The utilization of microbial concrete in Civil Engineering has become increasingly popular. From enhancing the durability of cementious materials to improving the sand properties, from repairing the limestone monuments, sealing of concrete cracks to highly durable bricks, it has been successful in one and all. This technology also offers the advantage of being novel and eco- friendly. Even though the MICCP process has many advantages, further study is required to overcome the limitations to use of this technology prior to its commercialization.

\section{Conflict of Interest}

The authors declare that they have no competing interests.

\section{Bibliography}

1. Bhutange SP., et al. "Role of biocementation to improve mechanical properties of mortar". Nucleic acid and Molecular Biology 44:50 (2019): 1-8.

2. Phutela U and Parmar M. "Isolation of ureolytic bacteria from different sources and their characterization". Asian journal of bio science 12:1 (2017): 21-25.

3. Jroundi F., et al. "Protection and consolidation of stone heritage by self-inoculation with indigenous carbonatogenic bacterial communities". Nature Communications 8: 279 (2017): 1-13.

4. Gavimath C., et al. "Potential application of bacteria to improve the strength of cement concrete". International Journal of Advance Biotech and Research 31 (2012): 541-544.

5. Sassoni E., et al. "The use of hydroxyapatite as a new inorganic consolidant for damaged carbonate stones". Journal of Cultural Heritage 12 (2011): 346-355.

6. Giorgi R., et al. "New methodologies for the conservation of cultural heritage: Micellar solutions, microemulsions, and hydroxide nanoparticles". Accounts of Chemical Research 15.43 (2010): 695-704.

7. Rodriguez-Navarro C., et al. "Influence of substrate mineralogy on bacterial mineralization of calcium carbonate: implications for stone conservation". Applied and Environmental Microbiology 78.11 (2012): 4017-4029.

8. Hamilton WA. "Microbially influenced corrosion as a model system for the study of metal microbe interactions: a unifying electron transfer hypothesis". Biofouling 19.1 (2003): 65-76.

9. Muynck W., et al. "Bacterial carbonate precipitation as an alternative surface treatment for concrete. Construction and Building Materials" Construction and Building Materials 22:8 (2008): 875-885.

10. Bazylinski DA., et al. "Modes of biomineralization of magnetite by microbes". Geomicrobiology Journal 24 (2007): 465-475.

11. Benzerara K., et al. "Significance, mechanisms and environmental implications of microbial biomineralization." Comptes Rendus Geoscience 343: 2-3 (2011): 160-167. 
12. Phillips AJ., et al. "Engineered applications of ureolytic biomineralization: a review”. Biofouling 29: 6 (2013): 715-733.

13. DeJong JT., et al. "Bio-mediated soil improvement". Ecological Engineering 36 (2010): 197-210.

14. Hammes $\mathrm{F}$ and Verstraete $\mathrm{W}$. "Key roles of $\mathrm{pH}$ and calcium metabolism in microbial carbonate precipitation". Reviews in Environmental Science and Biotechnology 1 (2002): 3-7.

15. Knorre H and Krumbein KE. "Bacterial calcification". Microbial Sediments, Springer-Verlag, Berlin.

16. Tiano P., et al. "Biomediated reinforcement of weathered calcareous stones". Journal of Cultural Heritage 7.1 (2006): 49-55.

17. Rodriguez-Navarro C., et al. "Consearvation of ornamental stones by Myхососcus Xanthus induced carbonate biomineralisation". Applied and Environmental Microbiology 69.4 (2003): 2182-2193.

18. De Muynck W., et al. "Microbial carbonate precipitation in construction materials: A review". Ecological Engineering 36.2 (2009): 118-136.

19. Roman SM., et al. "Biomineralization of carbonate and phosphate by moderately halophilic bacteria". FEMS Microbiology Ecology 61.2 (2007): 273-284.

20. Ercole $\mathrm{C}$, et al. "Bacterially induced mineralization of calcium carbonate: the role of exopolysaccharides and capsular polysaccharides". Microscopy Microanalysis 13.1 (2007): 42-50.

21. Khanafari A., et al. "An investigation of biocement production from hard water". Middle-East Journal of Scientific Research 7.6 (2011): 964-971.

22. Khattra SK., et al. "Study of Strength Variation of Concrete Using Ureolytic Bacteria". International Journal of Engineering and Applied Sciences 3.4 (2016): 2394-3661.

23. Boquet E., et al. "Production of calcite (calcium carbonate) crystals by soil bacteria is a general phenomenon". Nature 246: 5434 (1973): 527-529.

24. Ramachandran SK., et al. "Remediation of concrete using Micro- Organisms". American Concrete Institute Materials Journal 98: 1 (2001): 3-9.

25. Arunachalam KD., et al. "Studies on the characterization of Bio sealant properties of Bacillus sphaericus". International Journal of Engineering Science and Technology 2.3 (2010): 270-277.
26. Siddique R and Chahal NK. "Effect of ureolytic bacteria on concrete properties". Construction and Building Materials 25:10 (2011): 3791-3801.

Volume 4 Issue 9 September 2021

(C) All rights are reserved by Manisha Parmar and Priyanka Kamboj. 